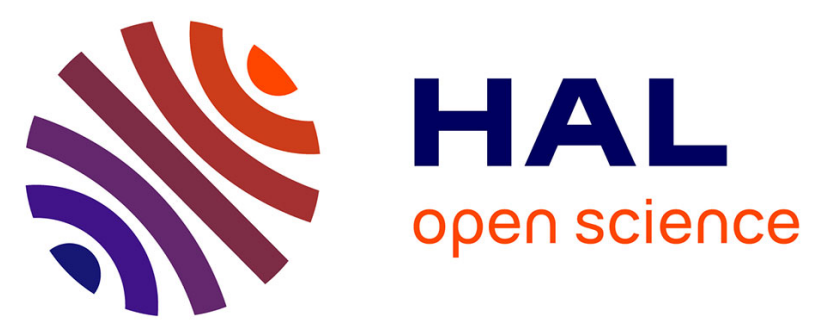

\title{
A facile access to new diazepines derivatives: Spectral characterization and crystal structures of 7-(thiophene- 2-yl)-5-(trifluoromethyl)-2,3-dihydro-1H-1,4-diazepine and 2-thiophene-4-trifluoromethyl-1,5-benzodiazepine
}

G. Ahumada, D. Carrillo, C. Manzur, M. Fuentealba, T. Roisnel, J.-R. Hamon

\section{To cite this version:}

G. Ahumada, D. Carrillo, C. Manzur, M. Fuentealba, T. Roisnel, et al.. A facile access to new diazepines derivatives: Spectral characterization and crystal structures of 7-(thiophene-2-yl)-5(trifluoromethyl)-2,3-dihydro-1H-1,4-diazepine and 2-thiophene-4-trifluoromethyl-1,5-benzodiazepine. Journal of Molecular Structure, 2016, 1125, pp.781-787. 10.1016/j.molstruc.2016.07.047 . hal01367194

HAL Id: hal-01367194

https://hal-univ-rennes1.archives-ouvertes.fr/hal-01367194

Submitted on 9 Nov 2016

HAL is a multi-disciplinary open access archive for the deposit and dissemination of scientific research documents, whether they are published or not. The documents may come from teaching and research institutions in France or abroad, or from public or private research centers.
L'archive ouverte pluridisciplinaire HAL, est destinée au dépôt et à la diffusion de documents scientifiques de niveau recherche, publiés ou non, émanant des établissements d'enseignement et de recherche français ou étrangers, des laboratoires publics ou privés. 
Graphical Abstract Synopsis

Both thienyl-containing 1,4-diazepine and 1,5-benzodiazepine (illustrated) were synthetized in a one-pot double condensation reaction of 2-thenoyltrifluoroacetone with ehtylenediamine and o-phenylene diamine, respectively. 


A facile access to new diazepines derivatives: spectral characterization and crystal structures of 7-(thiophene-2-yl)-5-(trifluoromethyl)-2,3-dihydro-1H1,4-diazepine and 2-thiophene-4-trifluoromethyl-1,5-benzodiazepine

\author{
Guillermo Ahumada ${ }^{\mathrm{a}, \mathrm{b}}$, David Carrillo ${ }^{\mathrm{a}}$, Carolina Manzur ${ }^{\mathrm{a}, *}$, \\ Mauricio Fuentealba ${ }^{a}$, Thierry Roisnel ${ }^{b}$, Jean-René Hamon,**
}

a Laboratorio de Química Inorgánica, Instituto de Química, Pontificia Universidad Católica de Valparaíso, Campus Curauma, Avenida Universidad 330, Valparaíso, Chile

b Institut des Sciences Chimiques de Rennes, UMR 6226 CNRS-Université de Rennes 1, Campus de Beaulieu, 35042 Rennes Cedex, France

* Corresponding authors.

e-mail address: cecilia.manzur@pucv.cl (C. Manzur)

e-mail address: jean-rene.hamon@univ-rennes1.fr (J.-R. Hamon) 


\begin{abstract}
The one-pot double condensation reaction of 2-thenoyltrifluoroacetone (2-TTA) with ethylendiamine or o-phenylenediamine, in a $2: 1$ stoichiometric molar ratio, leads to the formation of 7-(thiophene-2-yl)-5-(trifluoromethyl)-2,3-dihydro-1H-1,4-diazepine 2 and 2thiophene-4-trifluoromethyl-1,5-benzodiazepine 3, that were isolated in 56 and 53\% yields, respectively. The bis(trifluoroacetamide)ethylene derivative $\mathbf{1}$ was also isolated in 32\% yield as a side-product in the reaction of 2-TTA and ethylenediamine. Compounds 1-3 were fully characterized by elemental analysis, FT-IR and multinuclear $\left({ }^{1} \mathrm{H},{ }^{13} \mathrm{C}\right.$ and $\left.{ }^{19} \mathrm{~F}\right) \mathrm{NMR}$ spectroscopy. In addition, their molecular identities and geometries have been authenticated by single-crystal X-ray diffraction analysis. The spectroscopic and structural data confirm that the 1,4-diazepine 2 and the 1,5-benzodiazepine 3 exist in the imine-enamine and diimine tautomeric forms, respectively, both in solution and in the solid-state.
\end{abstract}

Keywords: 2-thenoyltrifluoroacetone; trifluoroacethyl-derivatives; diazepine; benzodiazepine; single-crystal X-ray diffraction; imine-enamine tautomerism

\title{
1. Introduction
}

Diazepines are found in various psychoactive pharmaceutical drugs, $v . g$. diazepam [1], and specifically as 1,4-diazepines [2]. Meanwhile, benzodiazepines have been thoroughly studied during a period of several decades, largely because of their relatively easy synthesis from common starting materials [3], and they have become of ever-increasing interest to investigators, inasmuch as their pharmacological activities (tranquilizers, substances that lower blood pressure, analgesics and sedative agents) [3]. On the other hand, the thienyl skeleton can be found in certain natural products and is also incorporated in several pharmacologically active compounds [4]. In medicinal chemistry, thiophene derivatives have been well known for their therapeutic applications [4]. Thus, it is attractive to obtain new heterocycles with potential biological properties from easy and minimum step reactions, involving inexpensive starting materials such as $\beta$-diketones which can be functionalized in three different sites of the molecule. In the last few years, our groups have been interested in the synthesis of $\beta$-diketones [5-7] as starting materials to be used in the preparation of heterocycles [8,9] and tridentate Schiff base ligands [10-12], via condensation with aliphatic 
or aromatic primary diamines [12,13], as well as for the design of asymmetric Schiff base ligands and their respective transition metal complexes [13]. Such reactions proceed via nucleophilic addition giving a hemiaminal intermediate containing the $-\mathrm{C}(\mathrm{OH})(\mathrm{NHR})$ - group which, depending on the $\mathrm{R}$ functional groups and the experimental conditions, evolves toward heterocycle or polydentate Schiff base compounds [14]. Now, our interest is focused on the use of the $\beta$-diketone 2-thenoyltrifluoroacetone (2-TTA) as starting materials for the synthesis of new thiophene-containing derivatives with potential electropolymerization properties. To the best of our knowledge, reactivity of the $\beta$-diketones containing thienyl moieties toward diamines has been scarcely reported in the literature [15]. The incorporation of thienyl units in the structure of a compound not only opens up opportunities to the formation of polymeric $[16,17]$ and metallopolymeric materials $[18,19]$, either through chemical or electrochemical oxidation of the thienyl units [20-22], but also to the development of new drugs [4].

With these ideas in mind, we report herein on the facile preparation of two new thienyl-containing diazepines, namely, the 7-(thiophene-2-yl)-5-(trifluoromethyl)-2,3dihydro-1H-1,4-diazepine 2 and the 2-thiophene-4-trifluoromethyl-1,5-benzodiazepine 3, formed upon condensation of 2-thenoyltrifluoroacetone with ethylenediamine and $O$ phenylenediamine, respectively (see formulas on Scheme 1). In addition, the known N,N'ethylene-bis(trifluoroacetamide) $\mathbf{1}$ was also isolated as a by-product. These compounds were fully characterized by analytical and spectroscopic techniques, and authenticated by single crystal X-ray diffraction analysis.

\section{Experimental}

\subsection{Materials and physical measurements}

Reactions were performed under dry dinitrogen or argon atmosphere using standard Schlenk techniques. Solvents were dried and distilled according to standard procedures [23]. All starting materials were purchased from commercial sources and used as received. Chromatographic purification was performed with Silica gel $60(0.063-0.200 \mu \mathrm{m})$. Solid-state FT-IR spectra were recorded on a Perkin-Elmer Model 1600 FT-IR spectrophotometer with $\mathrm{KBr}$ disks in the 4000 to $450 \mathrm{~cm}^{-1}$ range. NMR spectra were recorded at $298 \mathrm{~K}$ with a Bruker Avance III 400 spectrometer. All NMR spectra are reported in parts per million (ppm, $\delta$ ) relative to tetramethylsilane $\left(\mathrm{Me}_{4} \mathrm{Si}\right)$ for ${ }^{1} \mathrm{H}$ and ${ }^{13} \mathrm{C}$ NMR spectra, with the residual solvent proton and carbon resonances used as internal standards. Chemical shifts of ${ }^{19} \mathrm{~F}$ NMR spectra are referenced against external $\mathrm{CFCl}_{3}$. Coupling constants $(J)$ are reported in Hertz $(\mathrm{Hz})$, and 
integrations are reported as number of protons. The following abbreviations are used to describe peak patterns: $\mathrm{s}=$ singlet, $\mathrm{d}=$ doublet, $\mathrm{t}=$ triplet, $\mathrm{m}=$ multiplet, $\mathrm{br}=$ broad. ${ }^{1} \mathrm{H}$ and ${ }^{13} \mathrm{C}$ NMR chemical shift assignments are supported by data obtained from ${ }^{1} \mathrm{H}-{ }^{1} \mathrm{H}$ COSY, ${ }^{1} \mathrm{H}-$ ${ }^{13} \mathrm{C}$ HMQC, and ${ }^{1} \mathrm{H}_{-}{ }^{13} \mathrm{C}$ HMBC NMR experiments. Elemental analyses were conducted on a Thermo-FINNIGAN Flash EA 1112 CHNS/O analyzer by the Microanalytical Service of the Centre Regional de Mesures Physiques de l'Ouest (CRMPO) at the Université de Rennes 1, France. Melting points were determined in evacuated capillaries on a Kofler Bristoline melting point apparatus and were not corrected.

\subsection{Reaction of 2-TTA with ethylenediamine: isolation of N,N'-etilene-} bis(trifluoroacetamide) (1) and of 7-(thiophene-2-yl)-5-(trifluoromethyl)-2,3-dihydro-1H-

\section{1,4-diazepine (2)}

In a Schlenk tube loaded with a magnetic stirrbar, $0.50 \mathrm{~g}(2.25 \mathrm{mmol})$ of 2-TTA were dissolved in $30 \mathrm{~mL}$ of dry ethanol. After $5 \mathrm{~min}$. of stirring, $0.08 \mathrm{~mL}$ (1.25 mmol) of 1,2ethylendiamine was added dropwise by syringe. The solution turned light green. After refluxing for $12 \mathrm{~h}$, the reaction mixture was cooled to room temperature (r.t.), the solvent was evaporated and the residue dried under vacuum. The oily residue was extracted with $\mathrm{CH}_{2} \mathrm{Cl}_{2}$. The extracts were combined and concentrated before being kept at $-30{ }^{\circ} \mathrm{C}$ in the freezer overnight. The white precipitate that deposited was filtered off and washed with cold hexane and dried under vacuum for $2 \mathrm{~h}$, to give $0.10 \mathrm{~g}(0.40 \mathrm{mmol}, 32 \%$ yield) of bis-acetamide 1 (Rf $0.80,1: 1$ hexane/dichloromethane $(\mathrm{v} / \mathrm{v})$ as eluent). Recristallyzation by slow evaporation of a methanol solution of $\mathbf{1}$ at r. t. produces suitable colorless single crystals for X-ray diffraction study. M.p. $190{ }^{\circ} \mathrm{C}$. Anal. Calcd for $\mathrm{C}_{6} \mathrm{H}_{6} \mathrm{~F}_{6} \mathrm{~N}_{2} \mathrm{O}_{2}\left(252.12\right.$ gmol $\left.^{-1}\right)$ : C, 28.58; H, 2.40; N, 11.11. Found: C, 28.60; H, 2.50; N, 11.00. FT-IR (KBr, cm $\left.{ }^{-1}\right): 3303(\mathrm{~s}) v(\mathrm{~N}-\mathrm{H}), 3109(\mathrm{w}) v(\mathrm{C}-$ $\mathrm{H}$ arom), 2969(vw) $v\left(\mathrm{C}-\mathrm{H}\right.$ aliph), 1705 (vs) $v(\mathrm{C}=\mathrm{O}), 1528(\mathrm{~s}) \delta(\mathrm{N}-\mathrm{H}) .{ }^{1} \mathrm{H}$ NMR $(400 \mathrm{MHz}$, $\left.\left(\mathrm{CD}_{3}\right)_{2} \mathrm{CO}\right): 3.58\left(\mathrm{~s}, 4 \mathrm{H}, \mathrm{CH}_{2} \mathrm{CH}_{2}\right), \mathrm{NH}$ proton not observed. ${ }^{13} \mathrm{C}\left\{{ }^{1} \mathrm{H}\right\} \mathrm{NMR}(100 \mathrm{MHz}$, $\left.\left(\mathrm{CD}_{3}\right)_{2} \mathrm{CO}\right): 38.53\left(\mathrm{CH}_{2} \mathrm{CH}_{2}\right), 117.54\left(\mathrm{q},{ }^{1} J_{\mathrm{C}, \mathrm{F}}=285 \mathrm{~Hz}, \mathrm{CF}_{3}\right), 205.26(\mathrm{C}=\mathrm{O}) .{ }^{19} \mathrm{~F}$ NMR $(366$ $\left.\mathrm{MHz},\left(\mathrm{CD}_{3}\right)_{2} \mathrm{CO}\right):-76.96\left(\mathrm{CF}_{3}\right)$.

The above dichloromethane filtrate and hexane washings were combined, concentrated and the residual crude oil was absorbed on a column packed with silica gel (grade 60). Elution was carried out with hexane/dichloromethane mixture 1:1 (Rf. 0.95) and the collected colorless solution taken to dryness, affording $0.17 \mathrm{~g}(0.70 \mathrm{mmol}, 56 \%$ yield $)$ of the diazepine $\mathbf{2}$ as a white powder. Recristallyzation by slow evaporation of a methanol solution of $\mathbf{2}$ at r. t. afforded suitable single crystals for X-ray diffraction study. M.p. $103{ }^{\circ}$ C. Anal. Calcd for 
$\mathrm{C}_{10} \mathrm{H}_{9} \mathrm{~F}_{3} \mathrm{~N}_{2} \mathrm{~S}$ (246.25 gmol $\left.^{-1}\right)$ : C, 48.77; H, 3.68; N, 11.38; S, 13.02. Found: C, 48.18; H, 3.42; $\mathrm{N}, 10.85 ; \mathrm{S}, 12.67$. FT-IR $\left(\mathrm{KBr}, \mathrm{cm}^{-1}\right): 3210(\mathrm{~s}) v(\mathrm{~N}-\mathrm{H}), 3108(\mathrm{~m}) v(\mathrm{C}-\mathrm{H}$ arom $), 2962(\mathrm{vw}) v(\mathrm{C}-$ $\mathrm{H}$ aliph), 1618 (vs) $v(\mathrm{C}=\mathrm{C}), 1528(\mathrm{~s}) v(\mathrm{C}=\mathrm{N}) .{ }^{1} \mathrm{H} \mathrm{NMR}\left(400 \mathrm{MHz}, \mathrm{CDCl}_{3}\right): 3.56($ br s, $2 \mathrm{H}$, $\left.\mathrm{NCH}_{2} \mathrm{CH}_{2} \mathrm{NH}\right), 3.99$ (br s, $\left.2 \mathrm{H}, \mathrm{NCH}_{2} \mathrm{CH}_{2} \mathrm{NH}\right), 5.53(\mathrm{~s}, 1 \mathrm{H}, \mathrm{CH}=\mathrm{C}), 7.07\left(\mathrm{dd},{ }^{3} \mathrm{~J}_{\mathrm{H}, \mathrm{H}}=5.1\right.$ and $3.7 \mathrm{~Hz}, 1 \mathrm{H}, \mathrm{H}-4), 7.31\left(\mathrm{dd},{ }^{3} J_{\mathrm{H}, \mathrm{H}}=3.7 \mathrm{~Hz},{ }^{4} J_{\mathrm{H}, \mathrm{H}}=1.1 \mathrm{~Hz}, 1 \mathrm{H}, \mathrm{H}-3\right), 7.37\left(\mathrm{dd},{ }^{3} J_{\mathrm{H}, \mathrm{H}}=5.1 \mathrm{~Hz}\right.$,

$\left.{ }^{4} J_{\mathrm{H}, \mathrm{H}}=1.1 \mathrm{~Hz}, 1 \mathrm{H}, \mathrm{H}-5\right)$; NH proton not observed. ${ }^{13} \mathrm{C}\left\{{ }^{1} \mathrm{H}\right\} \mathrm{NMR}\left(100 \mathrm{MHz}, \mathrm{CDCl}_{3}\right): 49.28$ $\left(\mathrm{NCH}_{2} \mathrm{CH}_{2} \mathrm{NH}\right), 56.01\left(\mathrm{NCH}_{2} \mathrm{CH}_{2} \mathrm{NH}\right), 87.59(\mathrm{CH}=\mathrm{C}), 121.15\left(\mathrm{q},{ }^{1} J_{\mathrm{C}, \mathrm{F}}=279 \mathrm{~Hz}, \mathrm{CF}_{3}\right)$, $126.64(\mathrm{C}-3), 127.75(\mathrm{C}-5), 127.91(\mathrm{C}-4), 141.49(\mathrm{C}-2), 150.98(\mathrm{C}=\mathrm{N}), 154.68(\mathrm{CH}=\mathrm{C}) .{ }^{19} \mathrm{~F}$ $\mathrm{NMR}\left(366 \mathrm{MHz}, \mathrm{CDCl}_{3}\right):-70.66\left(\mathrm{CF}_{3}\right)$.

\subsection{Synthesis of 2-thiophene-4-trifluoromethyl-1,5-benzodiazepine (3)}

In a Schlenk tube loaded with a magnetic stirrer, $1.00 \mathrm{~g}(4.50 \mathrm{mmol})$ of 2-TTA and $0.25 \mathrm{~g}(2.31 \mathrm{mmol})$ of $o$-phenylenediamine were dissolved in $30 \mathrm{~mL}$ of ethanol. After 5 minutes of stirring the solution was taken to reflux for $18 \mathrm{~h}$. After cooling to r. t., the solvent was removed under vacuum. The oily residue was extracted with $n$-hexane, the extracts were combined and evaporated to dryness to afford $0.30 \mathrm{~g}(1.20 \mathrm{mmol}, 53 \%$ yield $)$ of $3(\mathrm{Rf}=0.4$, 1:1 hexane/dichloromethane (v/v) as eluent). Recrystallization by slow evaporation of a $n$ hexane solution of $\mathbf{3}$ at r. t. produced suitable pale green single crystals for X-Ray diffraction studies. M.p. $82{ }^{\circ} \mathrm{C}$. Anal. Calcd for $\mathrm{C}_{14} \mathrm{H}_{9} \mathrm{~F}_{3} \mathrm{~N}_{2} \mathrm{~S}$ (294.29 gmol $\left.^{-1}\right)$ : C, 57.14; H, 3.08; N, 9.52; S, 10.90. Found: C, 56.82; H, 3.40; N, 9.42; S, 10.21. FT-IR $\left(\mathrm{KBr}, \mathrm{cm}^{-1}\right)$ : 3100(vw), 3068(vw) $v\left(\mathrm{C}-\mathrm{H}\right.$ arom), 1604(m) $v(\mathrm{C}=\mathrm{C}), 1572(\mathrm{vs}) v(\mathrm{C}=\mathrm{N}) .{ }^{1} \mathrm{H}$ NMR (400 MHz, DMSO-d $)$ : $3.73\left(\right.$ br s, $\left.2 \mathrm{H}, \mathrm{CH}_{2}\right), 7.23\left(\mathrm{dd},{ }^{3} J_{\mathrm{H}, \mathrm{H}}=4.8\right.$ and $\left.3.9 \mathrm{~Hz}, 1 \mathrm{H}, \mathrm{H}-4\right), 7.41\left(\mathrm{~m}, 1 \mathrm{H}, \mathrm{C}_{6} \mathrm{H}_{4}\right), 7.49$ $\left(\mathrm{m}, 2 \mathrm{H}, \mathrm{C}_{6} \mathrm{H}_{4}\right), 7.54\left(\mathrm{~d},{ }^{3} J_{\mathrm{H}, \mathrm{H}}=7.9,1 \mathrm{H}, \mathrm{C}_{6} \mathrm{H}_{4}\right), 7.86\left(\mathrm{dd},{ }^{3} J_{\mathrm{H}, \mathrm{H}}=5.0 \mathrm{~Hz},{ }^{4} J_{\mathrm{H}, \mathrm{H}}=1.1 \mathrm{~Hz}, 1 \mathrm{H}\right.$, $\mathrm{H}-5), 8.08\left(\mathrm{~d}, J_{\mathrm{H}, \mathrm{H}}=3.5 \mathrm{~Hz}, 1 \mathrm{H}, \mathrm{H}-3\right) .{ }^{13} \mathrm{C}\left\{{ }^{1} \mathrm{H}\right\}$ NMR (100 MHz, DMSO-d $\left.)_{6}\right): 33.21\left(\mathrm{CH}_{2}\right)$, $117.89\left(\mathrm{q},{ }^{1} J_{\mathrm{C}, \mathrm{F}}=282 \mathrm{~Hz}, \mathrm{CF}_{3}\right), 126.37$ (C-2), 128.57 (C-5), 128.89 (C-4), 129.24 (C-3), $134.18\left(\mathrm{CH}, \mathrm{C}_{6} \mathrm{H}_{4}\right), 137.27\left(\mathrm{CH}, \mathrm{C}_{6} \mathrm{H}_{4}\right), 140.77\left(\mathrm{CN}, \mathrm{C}_{6} \mathrm{H}_{4}\right), 149.71\left(\mathrm{CN}, \mathrm{C}_{6} \mathrm{H}_{4}\right), 169.7$ $(\mathrm{C}=\mathrm{N}) .{ }^{19} \mathrm{~F}$ NMR $\left(366 \mathrm{MHz}, \mathrm{DMSO}-d_{6}\right):-70.29\left(\mathrm{CF}_{3}\right)$.

\subsection{X-ray Crystal Structure Determinations}

Crystallographic measurements were carried out for $\mathbf{1}$ at $\mathrm{T}=150(2) \mathrm{K}$ on a APEXII Bruker-AXS diffractometer equipped with a bidimensional CCD detector, for 2 at $\mathrm{T}=298(2)$ $\mathrm{K}$ on a Bruker D8 QUEST diffractometer equipped with a bidimensional CMOS Photon100 detector, and for 3 at $\mathrm{T}=120(2) \mathrm{K}$ on a Rigaku Mini CCD with Saturn 724+ CCD area detector diffractometer, using in the three cases graphite-monochromated Mo-K $\alpha$ radiation $(\lambda$ 
$=0.71073 \AA$ ). A single crystal of both 1 and 3 was coated in Paratone-N oil, mounted onto a nylon loop and transferred to the cold gas stream of the cooling device, while a crystal of 2 was mounted on top of glass fiber in a random orientation. The structures of $\mathbf{1}$ and $\mathbf{3}$ were solved by direct methods using the SIR97 program [24], and then refined with full-matrix least-square (1.s.) methods based on $F^{2}$ (SHELXL-97) [25]. The structure of 2 was solved by direct methods using OLEX2 [26] and refined by full matrix 1.s. methods based on $F^{2}$ [25]. In 2, the 2-thienyl group of one molecule in the asymmetric unit is heavily disordered in a 70:30 ratio. The model for this group was constructed from the mean distances calculated from more than 100 similar structures from the Cambridge Structural Database (CSD) [27]. DFIX instruction restrains were used with these bond lengths with a standard uncertainty of $0.01 \AA$. FLAT constrain instructions were applied in order to keep the planarity of the 2-thiophene rings with a standard uncertainty of $0.005 \AA^{3}$. Finally, EXYZ restrains was used to set the positions of $\mathrm{C} 7, \mathrm{C} 8$ and $\mathrm{C} 7 \mathrm{~A}, \mathrm{C} 8 \mathrm{~A}$ to be identical. In the same manner, the $-\mathrm{CF}_{3}$ groups of the four molecules in the asymmetric unit exhibit rotational disorder in a 54:46, 52:48, 50:50, and 63:37 ratios. The occupancies were freely refined or manually set to 50:50 ratio. In both cases, EADP constrains were applied to set the anisotropic ellipsoid displacement to be the same for each pair of atoms. All the disordered models impact the structural quality raising the $\mathrm{R} 1$ and $w \mathrm{R}_{2}$ factors to acceptable values of 0.0993 and 0.2397 , respectively. For the three compounds, non-hydrogen atoms were refined with anisotropic displacement parameters. In 1, the amide- $\mathrm{H}$ atom was found by difference synthesis and refined isotropically. All other $\mathrm{H}$ atoms were included in their calculated positions, assigned fixed isotropic thermal parameters and constrained to ride on their parent atoms. A summary of the details about crystal data, collection parameters and refinement are documented in Table 1, and additional crystallographic details are in the CIF files. ORTEP views were drawn using Olex2 software [26].

Table 1 Crystallographic data, details of data collection and structure refinement parameters for compounds 1-3.

\begin{tabular}{llll}
\hline & \multicolumn{1}{c}{$\mathbf{1}$} & \multicolumn{1}{c}{$\mathbf{2}$} & \multicolumn{1}{c}{$\mathbf{3}$} \\
\hline Empirical formula & $\mathrm{C}_{6} \mathrm{H}_{6} \mathrm{~F}_{6} \mathrm{~N}_{2} \mathrm{O}_{2}$ & $\mathrm{C}_{10} \mathrm{H}_{9} \mathrm{~F}_{3} \mathrm{~N}_{2} \mathrm{~S}$ & $\mathrm{C}_{14} \mathrm{H}_{9} \mathrm{~F}_{3} \mathrm{~N}_{2} \mathrm{~S}$ \\
Formula mass $\left(\mathrm{g} \mathrm{mol}{ }^{-1}\right)$ & 252.13 & 246.25 & 294.29 \\
Collection T $(\mathrm{K})$ & $150(2)$ & $298(2)$ & $120(2)$ \\
Crystal system & Triclinic & Monoclinic & Orthorhombic \\
Space group & $\mathrm{P}-1$ & $\mathrm{P} 2_{1}$ & Pbca \\
$\mathrm{a}(\AA)$ & $5.0214(5)$ & $11.3074(4)$ & $8.442(2)$ \\
$\mathrm{b}(\AA)$ & $6.6096(6)$ & $16.3026(7)$ & $19.213(6)$ \\
$\mathrm{c}(\AA)$ & $7.6807(7)$ & $11.8394(4)$ & $31.120(9)$ \\
$\alpha\left(^{\circ}\right)$ & $111.233(4)$ & 90 & 90
\end{tabular}




\section{ACCEPTED MANUSCRIPT}

\begin{tabular}{|c|c|c|c|}
\hline$B\left({ }^{\circ}\right)$ & $95.350(4)$ & $90.623(2)$ & 90 \\
\hline$\gamma\left(\left(^{\circ}\right)\right.$ & $98.213(4)$ & 90 & 90 \\
\hline $\mathrm{V}\left(\AA^{3}\right)$ & $232.25(4)$ & 2182.35 & $5047(2)$ \\
\hline $\mathrm{Z}$ & 1 & 8 & 16 \\
\hline Dcalcd $\left(\mathrm{g} \mathrm{cm}^{-3}\right)$ & 1.803 & 1.499 & 1.549 \\
\hline Crystal size (mm) & $0.58 \times 0.13 \times 0.06$ & $0.342 \times 0.186 \times 0.118$ & $0.53 \times 0.33 \times 0.18$ \\
\hline $\mathrm{F}(000)$ & 126 & 1008.0 & 2400.0 \\
\hline Absorption coefficient $\left(\mathrm{mm}^{-1}\right)$ & 0.209 & 0.310 & 0.283 \\
\hline$\theta$ range $\left(^{\circ}\right)$ & 2.88 to 27.51 & 2.126 to 25.437 & 2.12 to 25 \\
\hline Range h,k, 1 & $-6 / 6,-8 / 8,-9 / 9$ & $-14 / 14,-20 / 20,-14 / 14$ & $-10 / 10,-22 / 22,-37 / 37$ \\
\hline No. independent refl. & 3337 & 47970 & 60917 \\
\hline No. unique refl. $(>2)$ & 1048 & 8936 & 4431 \\
\hline Comp. to $\theta_{\max }(\%)$ & 91.4 & 99.8 & 99.9 \\
\hline Max/min transmission & $0.988 / 0.897$ & $1.00 / 0.9173$ & $0.950 / 0.894$ \\
\hline Data/restraints/parameters & $984 / 0 / 76$ & $8936 / 13 / 575$ & $4431 / 0 / 361$ \\
\hline Final $R$ indices $[I>2 \sigma(I)]$ & $\begin{array}{l}\mathrm{R} 1=0.0490, \quad w R 2= \\
0.1227\end{array}$ & $\begin{array}{l}\mathrm{R} 1=0.0816, \mathrm{wR} 2= \\
0.2203\end{array}$ & $\begin{array}{l}\mathrm{R} 1=0.0401, \quad \mathrm{wR} 2= \\
0.1031\end{array}$ \\
\hline $\mathrm{R}$ indices (all data) & $\begin{array}{l}\mathrm{R} 1=0.0761, \quad \mathrm{wR} 2= \\
0.1421\end{array}$ & $\begin{array}{l}\mathrm{R} 1=0.0993, \mathrm{wR} 2= \\
0.2397\end{array}$ & $\begin{array}{l}\mathrm{R} 1=0.0445, \quad \mathrm{wR} 2= \\
0.1114\end{array}$ \\
\hline Goodness of fit $/ \mathrm{F}^{2}$ & 1.038 & 1.045 & 1.006 \\
\hline Largest diff. peak/hole $\left(\mathrm{e} \mathrm{A}^{-3}\right)$ & $0.273 /-0.317$ & $0.70 /-0.49$ & $0.616 /-0.73$ \\
\hline
\end{tabular}

\section{Results and discussion}

\subsection{Syntheses and characterization}

Reactions of 2-TTA with ethylenediamine in a 2:1 stoichiometric ratio, in refluxing ethanol for $12 \mathrm{~h}$, leads to the formation of the 7-(thiophene-2-yl)-5-(trifluoromethyl)-2,3dihydro-1H-1,4-diazepine 2, isolated in 56\% yield as a white powder (Scheme 1). This compound has been briefly mentioned in the literature [28], being obtained in a three-step procedure and identified by IR and ${ }^{1} \mathrm{H}$ NMR spectroscopy. In contrast, reaction of 2-TTA with 1,2-phenylenediamine under similar experimental conditions (see Section 2.3), afforded only the 2-thiophene-4-trifluoromethyl-1,5-benzodiazepine 3 (Scheme 1) that was isolated as a pale green solid, in 53\% yield. Both diazepines 2 and 3 are air and moisture insensitive, thermally stable, exhibiting very good solubility in common organic solvents. Their composition and identity were deduced from satisfactory elemental analysis that is consistent with the proposed formulas, FT-IR and multinuclear NMR spectroscopy (see Section 2), and single-crystal X-ray diffraction study (see Section 3.2). 


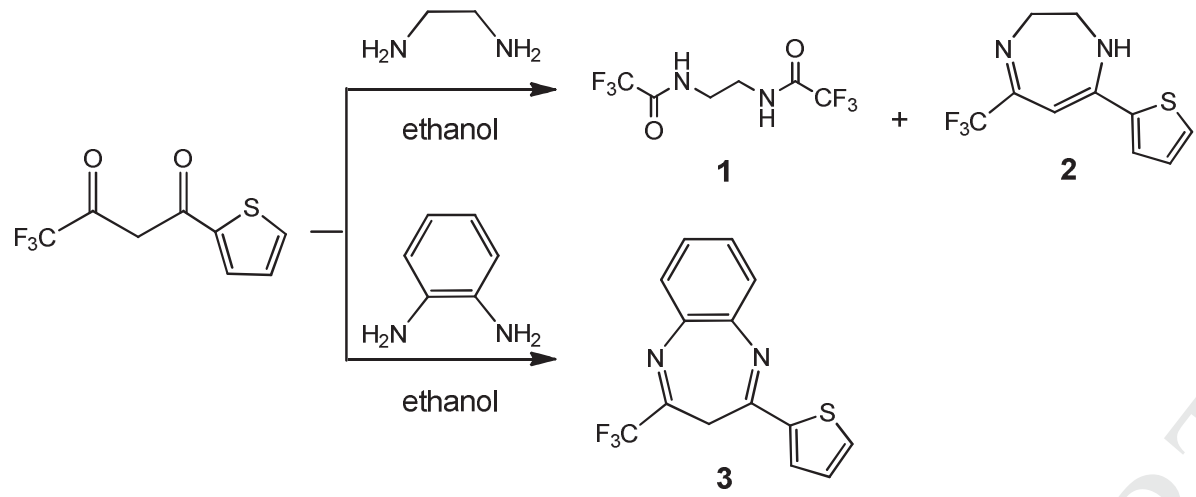

Scheme 1 Syntheses of diazepines $\mathbf{2}$ and $\mathbf{3}$ and of diacetamide $\mathbf{1}$

The solid-state FT-IR spectrum of diazepine 2 showed intense bands at 3210, 1618 and $1528 \mathrm{~cm}^{-1}$ due to the $\mathrm{N}-\mathrm{H}, \mathrm{C}=\mathrm{C}$ and $\mathrm{C}=\mathrm{N}$ stretching vibrations, respectively, thus suggesting that it does exist as its enamine tautomeric form in the solid phase. In the spectrum of benzodiazepine 3 the $\mathrm{N}-\mathrm{H}$ absorption is lacking, only bands at 1604 and $1572 \mathrm{~cm}^{-1}$ assigned to the $v(\mathrm{C}=\mathrm{C})$ and $v(\mathrm{C}=\mathrm{N})$ stretching modes, respectively, are observed, indicating in this case the presence of the bis-imine tautomer. Those findings have been confirmed by the X-ray crystal structure analysis of the two compounds (see section 3.2).

The formation of $\mathbf{2}$ and $\mathbf{3}$ was readily noticed in their respective ${ }^{1} \mathrm{H}$ NMR spectrum, showing in each case, a similar triple double-doublet multiplicity pattern for the H-3, H-4 and H-5 nuclei of the 2-thienyl fragment (see section 2.2 and 2.3 for details). Additionally, the protons of the ethylene unit of 2 resonated as two broad singlets at 3.56 and 3.99 ppm, whereas the protons of the $o$-phenylene unit of 3 gave rise to three resonances with integral ratio 1:2:1 (see Section 2.3). More interestingly, the ${ }^{1} \mathrm{H}$ NMR spectrum of diazepine 2, recorded in $\mathrm{CDCl}_{3}$ at $25^{\circ} \mathrm{C}$, presents a singlet at $5.53 \mathrm{ppm}$ characteristic of a vinylic proton, indicating that the molecule exists as its enamine tautomeric form in solution. By contrast, the ${ }^{1} \mathrm{H}$ NMR spectrum of the benzodiazepine 3, recorded at the same temperature in DMSO- $d_{6}$, showed a broad singlet at $3.73 \mathrm{ppm}$ integrating for $2 \mathrm{H}$, clearly evidencing that $\mathbf{3}$ does exist as its bis-imine tautomer. This different behavior could arise from the nature of the solvents used that is known to influence the position of the tautomeric equilibrium [29]. However, we reported previously that the ferrocenyl-containing 1,5-benzodiazepine counterpart of 3 exists as its $\beta$-diimine isomer in $\mathrm{CDCl}_{3}$ solution, with the methylene protons appearing at a broad singlet at $3.15 \mathrm{ppm}[8]$.

The proton decoupled ${ }^{13} \mathrm{C}$ NMR spectra of both diazepine derivatives confirm the existence of the imine-enamine and bis-imine tautomeric form for the diazepine 2 and its 
benzodiazepine counterpart 3 , respectively. In the imine-enamine tautomer 2 , the methyne carbon $\mathrm{C}(3)$, (see Fig. 1 for the labelling scheme) resonates at $87.59 \mathrm{ppm}$, while this $\mathrm{C}(3)$ carbon nucleus shows up at $33.21 \mathrm{ppm}$ in the $\beta$-diimine isomer 3 . On the other hand, the $\mathrm{C}(4)$ carbon experiences a downfield shift from $154.68 \mathrm{ppm}$ in 2 to $169.70 \mathrm{ppm}$ in 3 . Moreover, the ${ }^{19} \mathrm{~F}$ NMR spectral data confirm the presence of a unique tautomer for each compound with the $\mathrm{CF}_{3}$ substituent giving rise to a single sharp resonance at -70.66 and $-70.29 \mathrm{ppm}$, respectively.

Compounds 2 and 3 were formed by a cyclocondensation type reaction of the 2-TTA with ethylenediamine and o-phenylenediamine, respectively. In a first step, the monocondensation occurs affording the thenoylketoamine or the ketoimine which undergoes cyclocondensation to generate the expected diazepines. However, the formation of the 1,4 diazepine 2 is accompagned by the concommittent formation of the N,N-ethylenebis(trifloroacetamide) $\mathbf{1}$ as a side-product (see below). Probably, the greatest flexibility of the terminal free $\mathrm{NH}_{2}$ group of the hemiaminal intermediate facilitates the nucleophilic attack on the carbonyl group of a second molecule of $\beta$-diketone. An alternative procedure to synthesize 1,5-benzodiazepine derivatives has also been reported in the literature by cyclocondensation of a ketoamine promoted by transition metal cations [8].

The known bis(trifluoroacetamide)ethylene derivative 1 (Scheme 1) was, indeed, isolated upon precipitation at low temperature (see section 2.2), as an air and thermally stable, moisture insensitive white solid in 32\% yield. Compound $\mathbf{1}$ was mentioned earlier in the literature [30], being prepared in almost quantitative yield by acylation of ethylenediamine with trifluoroacetic anhydride. In addition to the published characterizations, we report here the ${ }^{13} \mathrm{C}\left\{{ }^{1} \mathrm{H}\right\}$ and ${ }^{19} \mathrm{~F}$ NMR spectral data as well as the crystal and molecular structure of this compound.

The solid-state FT-IR spectrum of $\mathbf{1}$ showed intense bands at 3303, 1705, 1528 and $1184 \mathrm{~cm}^{-1}$ attributed to the $v(\mathrm{~N}-\mathrm{H}), \quad v(\mathrm{C}=\mathrm{O}), \delta(\mathrm{N}-\mathrm{H})$ and $v(\mathrm{C}-\mathrm{N})$ stretching modes, respectively. The spectral data match those reported in chloroform solution $(1705,1565,1185$ $\mathrm{cm}^{-1}$ ) [30]. Only the sharp resonance at $3.58 \mathrm{ppm}$ due to the magnetically equivalent four ethylene protons was observed in the ${ }^{1} \mathrm{H}$ NMR spectrum. The N-H proton signal was probably hidden by the residual proton acetone; it appeared at $1.93 \mathrm{ppm}$ in the $\mathrm{CDCl}_{3}$ solution spectrum [30]. In the proton-decoupled ${ }^{13} \mathrm{C}$ NMR spectrum of $\mathbf{1}$, beside the expected singlets of the methylene and carbonyl carbon atoms at 38.53 and $205.26 \mathrm{ppm}$, respectively, the trifluoromethyl carbon resonated at $117.54 \mathrm{ppm}$ as a quartet with a ${ }^{1} J_{\mathrm{C}, \mathrm{F}}$ coupling constant of $285 \mathrm{~Hz}$. This is corroborated by a sharp singlet at $-76.96 \mathrm{ppm}$ in the ${ }^{19} \mathrm{~F}$ NMR spectrum. 


\subsection{X-ray Crystallographic Study}

Diffraction-quality single crystals for X-ray structure investigation were obtained for compounds 2 and 3 by slow evaporation of a saturated methanol and $n$-hexane solution, respectively. Perspective views of diazepines $\mathbf{2}$ and $\mathbf{3}$ with the atom labelling scheme are displayed in Fig. 1, with selected bond distances and angles listed in Tables 2 and 3, respectively. Compound 2 crystallizes in the monoclinic group P21 with four crystallographically independent molecules (2A-D) in the asymmetric unit. Compound 3 crystallizes in the orthorhombic group Pbca with two molecules in the asymmetric unit, which are also crystallographically independent (3A,B).

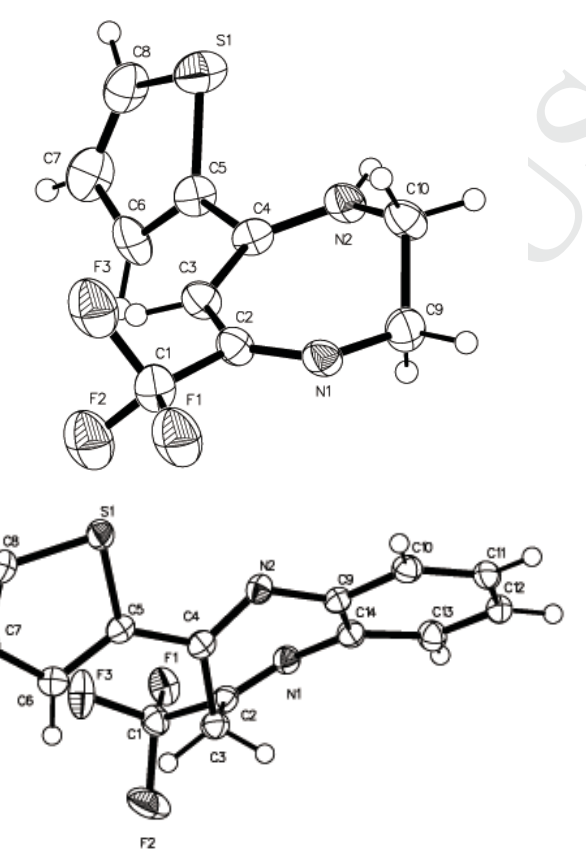

Fig. 1 Molecular structures of 2 (top) and 3 (bottom) with their respective atom numbering scheme. Hydrogen atoms are omitted for clarity. Thermal ellipsoids are drawn at 30 and 50\% probability levels for $\mathbf{2}$ and $\mathbf{3}$, respectively.

Interestingly, compound 2 presents a half-chair conformation where the plane containing the methylene $\mathrm{C}(9)$ carbon atom $[\mathrm{N}(1) \mathrm{C}(9) \mathrm{C}(10)]$ makes a dihedral angle of $23.93^{\circ}$ with the imine-enamine plane $[\mathrm{N}(1) \mathrm{C}(2) \mathrm{C}(3) \mathrm{C}(4) \mathrm{N}(2) \mathrm{C}(10)]$ (Fig. 1). In this latter plane, the average distance of the constituing atoms with respect to the 1.s. mean plane is of $0.091 \AA$ A. In 3, the $o$-phenylendiamine fragment $[\mathrm{C}(9)-\mathrm{C}(14), \mathrm{N}(1), \mathrm{N}(2)]$ adopts a co-planar configuration with an average distance of the atoms with the 1.s. mean plane of $0.021 \AA$. Bent away from this plane, the $[\mathrm{N}(1) \mathrm{C}(2) \mathrm{C}(3) \mathrm{C}(4) \mathrm{N}(2)]$ framework shows an envelop-type structure with the central carbon located out of the plane made by the four remaining atoms 
(Fig. 1). In both 2 and 3, atoms of the thienyl moiety are coplanar (average distance with the mean plane $=0.004$ and $0.0032 \AA$, respectively) and this plane is twisted by $43.18^{\circ}$ with respect to that of the imine-enamine fragment in 2 , and by $44.79^{\circ}$ with respect to the $O$ phenylenediamine mean plane in 3 (Fig. 1).

In agreement with FT-IR and NMR spectral data (see above), the crystal structures confirm that compounds 2 and $\mathbf{3}$ exist in the imine-enamine and diimine tautomeric forms, respectively. Two different $\mathrm{C}-\mathrm{N}$ bond distances are, indeed, found in the 1,4-diazepine 2: a long C-NH (average $=1.332 \AA$ ) and a short C-N (average = $1.280 \AA)($ see Table 2$)$, that are typical of single and double $\mathrm{C}-\mathrm{N}$ bonds, respectively [31]. This bonding situation is similar to that observed in the molecular structure of 5-chlorodifluoromethyl-7-phenyl-2,3-dihydro-1H1,4-diazepine, which exhibits also the imine-enamine tautomeric form in the solid-state [32]. By contrast, in the benzodiazepine 3 the two C-N bond lengths are almost identical averaging 1.273 and $1.291 \AA$ (see Table 3), in agreement with a $\beta$-diimine isomeric structure. Additionally, the [N-CCC-N] skeleton is also characterized by two different C-C bond distances averaging 1.443 and $1.374 \AA$ (Table 2) in the imine-enamine framework of 2 , while those two bonds are much longer and of similar length, averaging 1.507 and $1.517 \AA$ (Table 3 ), in the diimine isomer 3 . This is corroborated by the $29.2^{\circ}$ reduction of the bond angle at the central methine/methylene carbon on passing from $\mathbf{2}$ to 3 (Tables 2 and 3). 


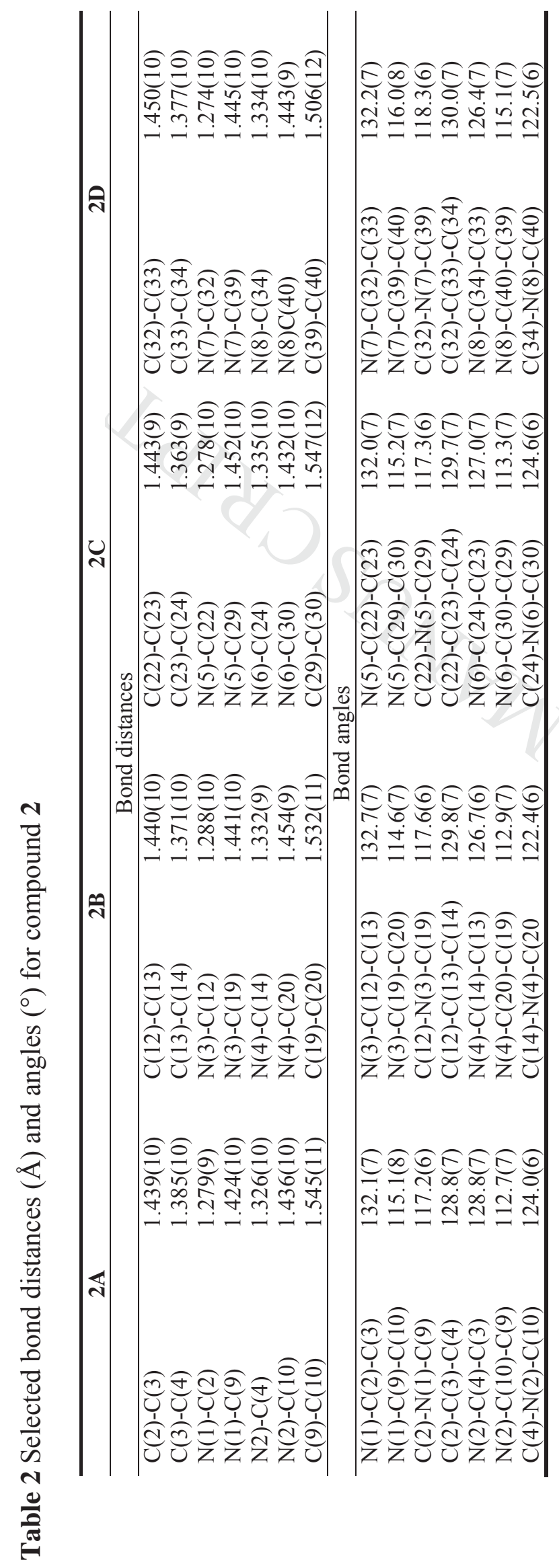


Table 3 Selected bond distances $(\AA)$ and angles $\left(^{\circ}\right)$ for compound 3

\begin{tabular}{|c|c|c|c|}
\hline \multicolumn{2}{|c|}{ 3A } & \multicolumn{2}{|c|}{ 3B } \\
\hline \multicolumn{4}{|c|}{ Bond distances } \\
\hline$C(2)-C(3)$ & $1.514(3)$ & $\mathrm{C}(16)-\mathrm{C}(17)$ & $1.501(3)$ \\
\hline$C(3)-C(4)$ & $1.518(3)$ & $\mathrm{C}(17)-\mathrm{C}(18)$ & $1.517(3)$ \\
\hline $\mathrm{N}(1)-\mathrm{C}(2)$ & $1.270(3)$ & $\mathrm{N}(3)-\mathrm{C}(16)$ & $1.275(3)$ \\
\hline $\mathrm{N}(1)-\mathrm{C}(14)$ & $1.413(3$ & $\mathrm{N}(3)-\mathrm{C}(28)$ & $1.415(3)$ \\
\hline N2)-C(4) & $1.291(3)$ & $\mathrm{N}(4)-\mathrm{C}(18)$ & $1.291(3)$ \\
\hline $\mathrm{N}(2)-\mathrm{C}(9)$ & $1.413(3)$ & $\mathrm{N}(4)-\mathrm{C}(23)$ & $1.414(3)$ \\
\hline $\mathrm{C}(9)-\mathrm{C}(14)$ & $1.411(3)$ & $\mathrm{C}(23)-\mathrm{C}(28)$ & $1.414(3)$ \\
\hline$S(1)-C(5)$ & $1.731(2)$ & $\mathrm{S}(2)-\mathrm{C}(19)$ & $1.734(2)$ \\
\hline $\mathrm{S}(1)-\mathrm{C}(8)$ & $1.714(2)$ & $\mathrm{S}(2)-\mathrm{C}(22)$ & $1.712(2)$ \\
\hline $\mathrm{F}(1)-\mathrm{C}(1)$ & $1.324(3)$ & $\mathrm{F}(4)-\mathrm{C}(15)$ & $1.321(3)$ \\
\hline $\mathrm{F}(2)-\mathrm{C}(1)$ & $1.342(3)$ & $\mathrm{F}(5)-\mathrm{C}(15)$ & $1.334(3)$ \\
\hline $\mathrm{F}(3)-\mathrm{C}(1)$ & $1.351(3)$ & $\mathrm{F}(6)-\mathrm{C}(15)$ & $1.347(3$ \\
\hline \multicolumn{4}{|c|}{ Bond angles } \\
\hline $\mathrm{N}(1)-\mathrm{C}(2)-\mathrm{C}(3)$ & $125.04(19)$ & $\mathrm{N}(3)-\mathrm{C}(16)-\mathrm{C}(17)$ & $125.6(2)$ \\
\hline $\mathrm{N}(1)-\mathrm{C}(14)-\mathrm{C}(9)$ & $124.36(19)$ & $\mathrm{N}(3)-\mathrm{C}(28)-\mathrm{C}(23)$ & $124.94(19)$ \\
\hline $\mathrm{C}(2)-\mathrm{N}(1)-\mathrm{C}(14)$ & 119.29(19) & $\mathrm{C}(16)-\mathrm{N}(3)-\mathrm{C}(28)$ & $120.59(19)$ \\
\hline $\mathrm{C}(2)-\mathrm{C}(3)-\mathrm{C}(4)$ & $104.78(17)$ & $\mathrm{C}(16)-\mathrm{C}(17)-\mathrm{C}(18)$ & $106.43(18)$ \\
\hline $\mathrm{N}(2)-\mathrm{C}(4)-\mathrm{C}(3)$ & $121.60(18)$ & $\mathrm{N}(4)-\mathrm{C}(18)-\mathrm{C}(17)$ & $122.33(19)$ \\
\hline $\mathrm{N}(2)-\mathrm{C}(9)-\mathrm{C}(14)$ & $125.65(19)$ & $\mathrm{N}(4)-\mathrm{C}(23)-\mathrm{C}(28)$ & $126.52(19)$ \\
\hline $\mathrm{C}(4)-\mathrm{N}(2)-\mathrm{C}(9)$ & 121.21(18) & $\mathrm{C}(18)-\mathrm{N}(4)-\mathrm{C}(23$ & $122.41(19)$ \\
\hline $\mathrm{C}(5)-\mathrm{S}(1)-\mathrm{C}(8)$ & $91.78(11)$ & $\mathrm{C}(19)-\mathrm{S}(2)-\mathrm{C}(22)$ & $91.48(11)$ \\
\hline
\end{tabular}

The molecular structure of the bis-acetamide $\mathbf{1}$ is shown in Fig. 2, with selected bond distances and angles given in the caption. Compound $\mathbf{1}$ crystallizes in the triclinic centrosymmetric space group $\mathrm{P}_{-1}$ with a half molecule in the asymmetric unit. It consists of two trifluoroacetamide fragments connected by an ethylene linker, forming monomeric units, with an inversion center located in the middle of the $\mathrm{H}_{2} \mathrm{C}-\mathrm{CH}_{2}$ bond. The acetamide core made of $\mathrm{C}(1), \mathrm{C}(5), \mathrm{O}(6)$ and $\mathrm{N}(7)$ is planar with the sum of bond angles about the central $\mathrm{C}(5)$ atom of $360.01^{\circ}$. The two nitrogen-carbon bond lengths, $\mathrm{N}(7)-\mathrm{C}(5)$ and $\mathrm{N}(7)-\mathrm{C}(8)$ of 1.321(3) and 1.457(3) $\AA$, respectively, are different as expected for $\mathrm{N}-\mathrm{C}\left(\mathrm{sp}^{2}\right)$ and $\mathrm{N}-\mathrm{C}\left(\mathrm{sp}^{3}\right)$ linkages [30]. The $\mathrm{C}(5)-\mathrm{O}(6)(1.225(2) \AA), \mathrm{C}(1)-\mathrm{C}(5)(1.525(3) \AA)$ and $\mathrm{O}(6)-\mathrm{C}(5)-\mathrm{C}(1)$ $\left(117.94(19)^{\circ}\right)$ bond lengths and angle, respectively, are similar to those measured for other structurally characterized trifluoroacetyl-containing organic compounds [32,33].

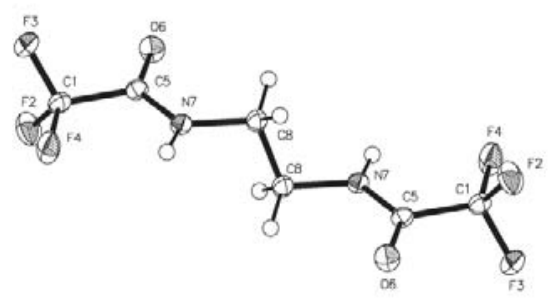


Fig. 2 Molecular structure of $\mathbf{1}$ with the atom numbering scheme. Hydrogen atoms have been omitted for clarity. Thermal ellipsoids are drawn at 50\% probability. Selected bond distances $[\AA]$ and angles [ $\left.{ }^{\circ}\right]$ : C(1)-F(2) 1.321(3), C(1)-F(3) 1.321(2), C(1)-F(4) 1.333(3), C(1)-C(5) 1.525(3), C(5)-O(6) 1.225(2), C(5)-N(7) 1.321(3), N(7)-C(8) 1.457(3), N(7)-H(7) 0.81(3), $\mathrm{C}(8)-\mathrm{C}(8)^{\# 1}$ 1.517(4); O(6)-C(5)-C(1) 117.94(19), O(6)-C(5)-N(7) 126.3(2), N(7)-C(5)-C(1) 115.77(18), $\quad \mathrm{C}(5)-\mathrm{N}(7)-\mathrm{C}(8) \quad 122.55(18), \quad \mathrm{N}(7)-\mathrm{C}(8)-\mathrm{C}(8)^{\# 1} \quad 110.2(2) . \quad$ Symmetry transformations used to generate equivalent atoms: \#1 -x, -y, -z.

The crystal packings of 1-3 are stabilized by intermolecular hydrogen bond interactions (Table 4). The intermolecular interactions $\mathrm{N}(7)-\mathrm{H}(7) \cdots \mathrm{O}(6)$ in $\mathbf{1}$ and $\mathrm{N}(2)$ $\mathrm{H}(2) \cdots \mathrm{N}(7)$ in 2 generates a chain type structure, while in compound 3 the intermolecular $\mathrm{C}(22)-\mathrm{H}(22 \mathrm{~A}) \cdots \mathrm{S}(1)$ interactions create a ladder-type structure (Fig. 3).
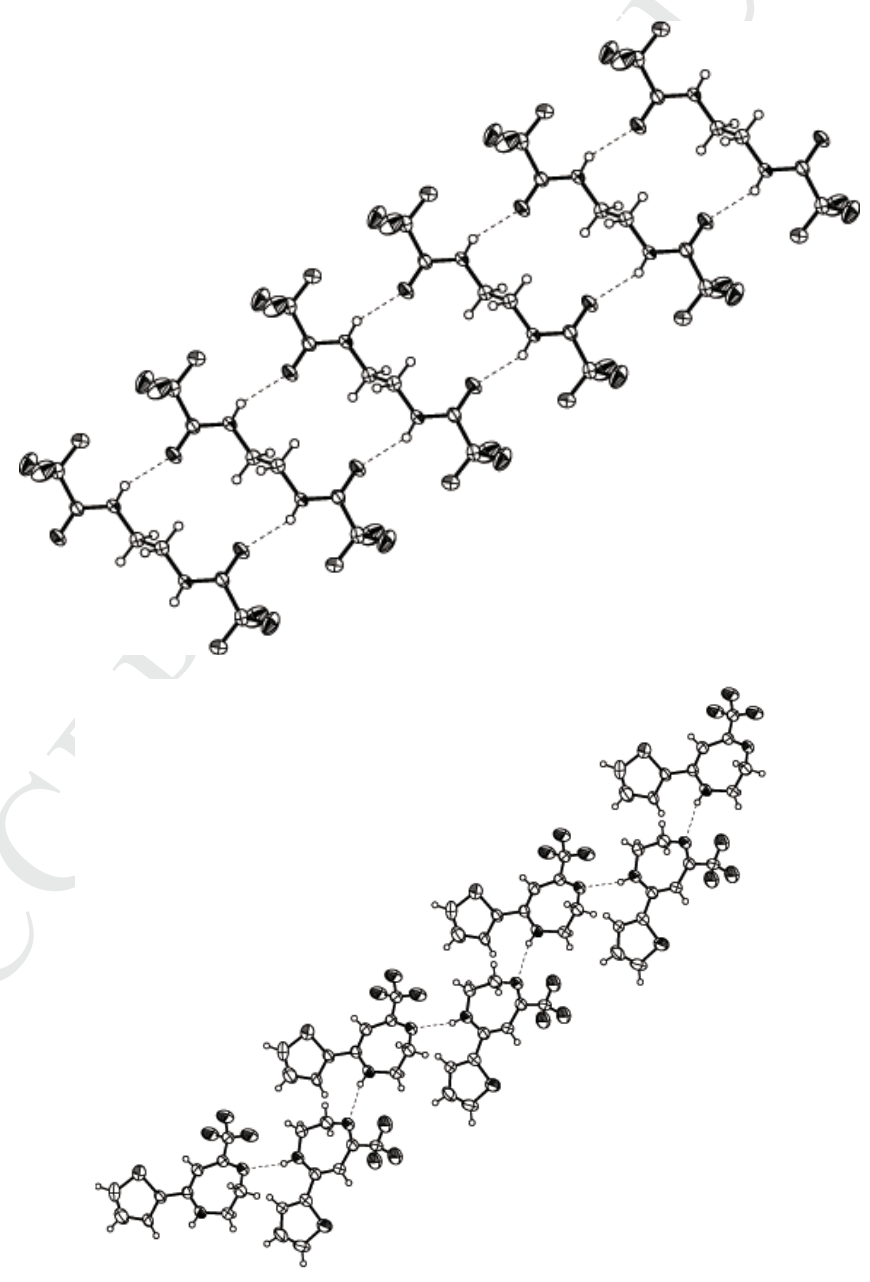


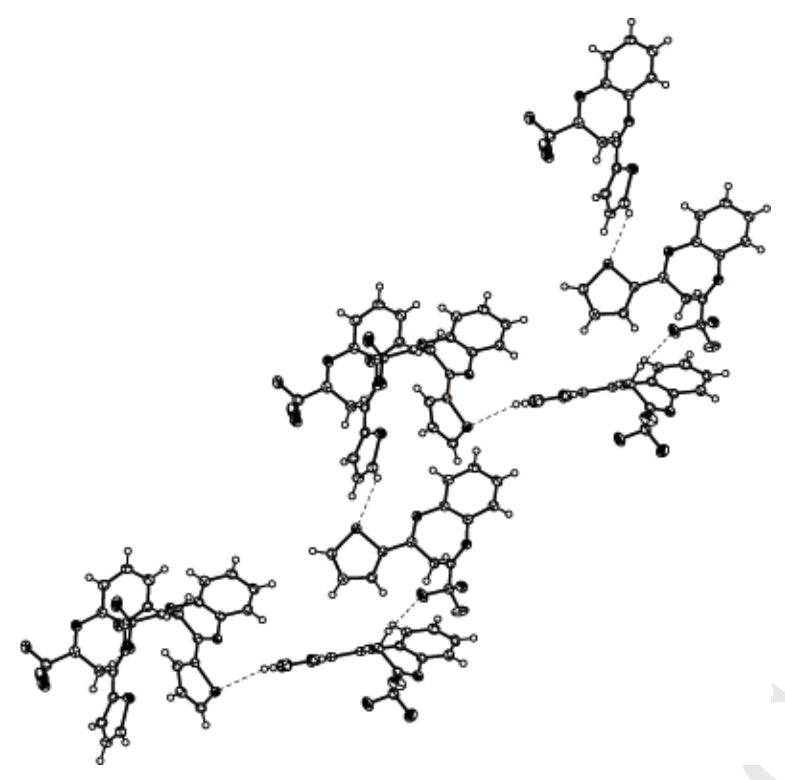

Fig. 3 Intermolecular hydrogen bond interactions observed in the solid-state structures of 1 (top), 2 (middle) and $\mathbf{3}$ (bottom).

Table 4 Hydrogen bond interactions parameters for compounds 1-3

\begin{tabular}{|c|c|c|c|c|c|}
\hline Compd & 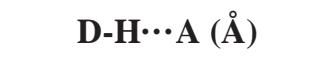 & D-H (A) & 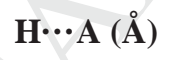 & D $\cdots A(\AA)$ & D-H $\cdots A\left({ }^{\circ}\right)$ \\
\hline & $\mathrm{N}(7)-\mathrm{H}(7) \cdots \mathrm{F}(4)$ & $0.80(3)$ & $2.28(3)$ & $2.628(3)$ & $108(3)$ \\
\hline \multirow[t]{3}{*}{1} & $\mathrm{~N}(7)-\mathrm{H}(7) \cdots \mathrm{O}(6)^{\mathrm{i}}$ & $0.80(3)$ & $2.06(3)$ & $2.772(3)$ & $149(3)$ \\
\hline & $\mathrm{C}(8)-\mathrm{H}(8 \mathrm{~B}) \cdots \mathrm{O}(6)$ & 0.99 & 2.48 & $2.840(3)$ & 101 \\
\hline & $\mathrm{N}(2)-\mathrm{H}(2) \cdots \mathrm{N}(7)^{\mathrm{ii}}$ & 0.86 & 2.19 & $3.023(9)$ & 163 \\
\hline \multirow[t]{3}{*}{2} & $\mathrm{~N}(4)-\mathrm{H}(4) \cdots \mathrm{N}(5)$ & 0.86 & 2.28 & 3.103 & 162 \\
\hline & $\mathrm{N}(6)-\mathrm{H}(6 \mathrm{~B}) \cdots \mathrm{N}(3)^{\mathrm{iii}}$ & 0.86 & 2.24 & 3.075 & 163 \\
\hline & $\mathrm{C}(17)-\mathrm{H}(17) \cdots \mathrm{F}(4)^{\mathrm{iv}}$ & 0.97 & 2.45 & $3.376(3)$ & 159 \\
\hline 3 & $\mathrm{C}(22)-\mathrm{H}(22 \mathrm{~A}) \cdots \mathrm{S}(1)^{\mathrm{v}}$ & 0.93 & 2.84 & $3.521(3)$ & 131 \\
\hline
\end{tabular}

Symmetry codes: (i) $-1+\mathrm{x}, \mathrm{y}, \mathrm{z}$ (ii) $1-\mathrm{x}, 1 / 2+\mathrm{y}, 2-\mathrm{z}$ (iii) $1+\mathrm{x}, \mathrm{y}, \mathrm{z}$ (iv) $1 / 2+\mathrm{x}, \mathrm{y}, 1 / 2-\mathrm{z}$ (v) $3 / 2$ $\mathrm{x}, 1 / 2+\mathrm{y}, \mathrm{z}$

\section{Conclusion}

In this work we describe a facile preparation of new diazepine derivatives containing the 2-thienyl unit. They were synthetized in a one-pot procedure by double condensation reaction of 2-thenoyltrifluoroacetone with either ethylene or $o$-phenylene primary diamine. In the case of ethylenediamine, the bis(trifluoroacetamide)ethylene derivative was also isolated. The compounds were all fully characterized using standard analytical and spectroscopic methods and authenticated by single crystal X-ray diffraction analysis, showing that the 1,4diazepine exists as its imine-enamine tautomeric form both in solution and in the solid-state, 
while the 1,5-benzodiazepine exists as its diimine isomer under the same physical conditions. Access to ONN-tridentate Schif base hemiligands containing a free terminal amino group, starting from the same reagents, is now under investigation.

\section{Acknowledgments}

Financial support from the Fondo Nacional de Desarrollo Científico y Tecnológico [FONDECYT (Chile), grant no. 1140903 (C.M. and D.C.)], FONDEQUIP [EQM130154 and EQM120095] and the Vicerrectoría de Investigación y Estudios Avanzados, Pontificia Universidad Católica de Valparaíso, Chile (C.M. and D.C.), the CNRS and the Université de Rennes 1 is gratefully acknowledged. This research has been performed as part of the Chilean-French International Associated Laboratory for "Inorganic Functional Materials" (LIAMIF-CNRS No836). The authors thank also Dr S. Sinbandhit (CRMPO, Rennes) for helpful assistance with NMR experiments. G.A. thanks the CONICYT (Chile) for a graduate fellowships, and Dr. C. W. Bielawski, University of Texas at Austin (USA) for his helpful discussions and advices during his internship in that University.

\section{Supplementary information}

CCDC 1482590 for $\mathbf{1}, 1480581$ for 2 and 1482591 for 3 contain the supplementary crystallographic data for this paper. These data can be obtained free of charge via http://www.ccdc.cam.ac.uk/conts/retrieving.html (or from the Cambridge Crystallographic Data Centre, 12, Union Road, Cambridge CB2 1EZ, UK; fax: +44 1223 336033).

\section{Appendix A. Supplementary data}

Supplementary data related to this article can be found at http://dx.doi.org/10.1016/j.molstruc. 


\section{References}

[1]

O. Keller, N. Steiger, L. Sternbach, 2-Aminomercapto- and 2-AminoalkylCaptobenzophenone Oximes, U.S Patent Office, No. 3442946 A, 1969.

[2] N.A. Meanwell, M.A. Walker, 1,4-Diazepines, in: A.R. Katritzky, C.A. Ramsden, E.F.V. Scriven, R.J.K. Taylor (Eds.), Comprehensive Heterocyclic Chemistry III, Elsevier, New York, 2008, Vol. 13, Chapter 12, pp. 183-235.

[3] G.A. Archer, L.E.O.H. Sternbach, Chem. Rev. 68 (1968) 747-784.

[4] R. Mishra, K.K. Jha, S. Kumar, I. Tomer, Pharm. Chemica 3 (2011) 38-54.

[5] G. Ahumada, T. Roisnel, S. Sinbandhit, C. Manzur, D. Carrillo, J.-R. Hamon, J. Organomet. Chem. 737 (2013) 1-6.

[6] N. Novoa, T. Roisnel, V. Dorcet, J.-R. Hamon, D. Carrillo, C. Manzur, F.Robin-Le Guen, N. Cabon, J. Organomet. Chem. 762 (2014) 19-28.

[7] G. Ahumada, T. Roisnel, J.-R. Hamon, D. Carrillo, C. Manzur, J. Chil. Chem. Soc. 58 (2013) 1963-1966.

[8] C. Gallardo, A. Trujillo, M. Fuentealba, A. Vega, D. Carrillo, C. Manzur, J. Chil. Chem. Soc. 52 (2007) 1266-1270.

[9] G. Ahumada, J.P. Soto, D. Carrillo, C. Manzur, T. Roisnel, J.-R. Hamon, J. Organomet. Chem. 770 (2014) 14-20.

[10] S. Celedon, M. Fuentealba, T. Roisnel, J.-R. Hamon, D. Carrillo, C. Manzur, Inorg. Chim. Acta 390 (2012) 184-189.

[11] N. Novoa, F. Justaud, P. Hamon, T. Roisnel, O. Cador, B. Le Guennic, C. Manzur, D. Carrillo, J.-R. Hamon, Polyhedron 86 (2015) 81-88.

[12] A. Trujillo, M. Fuentealba, D. Carrillo, C. Manzur, I. Ledoux-Rak, J.-R. Hamon, J.-Y. Saillard, Inorg. Chem. 49 (2010) 2750-2764.

[13] (a) S. Celedón, V. Dorcet, T. Roisnel, A. Singh, I. Ledoux-Rak, J.-R. Hamon, D. Carrillo, C. Manzur, Eur. J. Inorg. Chem. (2014) 4984-4993; (b) A. Trujillo, F. Justaud, L. Toupet, O. Cador, D. Carrillo, C. Manzur, J.-R. Hamon. New J. Chem. 35 (2011) 2027-2036; (c) M. Fuentealba, J.-R. Hamon, D. Carrillo, C. Manzur, New J. Chem. 31 (2007) 1815-1825; (d) J. Cisterna, V. Dorcet, C. Manzur, I. Ledoux-Rak, J.-R. Hamon, D. Carrillo, Inorg. Chim. Acta 430 (2015) 82-90; (e) N. Novoa, T. Roisnel, P. 
Hamon, S. Kahlal, C. Manzur, H. Minh Ngo, I. Ledoux-Rak, J.-Y. Saillard, D. Carrillo, J.-R. Hamon, Dalton Trans. 44 (2015) 18019-18037.

[14] J.-P. Costes, Polyhedron 6 (1987) 2169-2175.

[15] G. Malandrino, L.M.S. Perdicaro, G. Condorelli, I.L. Fragalà, P. Rossi, P. Dapporto, Dalton Trans. (2006) 1101-1106.

[16] J. Roncali, Chem. Rev. 92 (1992) 711-738.

[17] J. Roncali, J. Mater. Chem. 9 (1999) 1875-1893.

[18] G.R. Whittell, I. Manners, Adv. Mater. 19 (2007) 3439-3468.

[19] P. Audebert, P. Capdevielle, M. Maumy, New J. Chem. 16 (1992) 697-703.

[20] J.M. Xu, H.S.O. Chan, S.C. Ng, T.S. Chung, Synth. Met. 132 (2002) 63-69.

[21] M.O. Wolf, Adv. Mater. 13 (2001) 545-553.

[22] R.P. Kingsborough, T.M. Swager, Chem. Mater. 12 (2000) 872-874.

[23] W.L.F. Armarego, C.L.L. Chai, Purification of Laboratory 776 Chemicals, Fifth ed., Butterworth-Heinemann, Elsevier Inc., Amsterdam, The Netherlands, 2003.

[24] A. Altomare, M.C. Burla, M. Camalli, G. Cascarano, C. Giacovazzo, A. Guagliardi, A.G.G. Moliterni, G. Polidori, R. Spagna, J. Appl. Crystallogr. 32 (1999) 115-119.

[25] G.M. Sheldrick, Acta Crystallogr. A64 (2008) 112-122.

[26] O.V. Dolomanov, L.J. Bourhis, R.J. Gildea, J.A.K. Howard, H. Puschmann, J. Appl. Crystallogr. 42 (2009) 339-341.

[27] (a) C.R. Groom, I.J. Bruno, M.P. Lightfoot, S.C. Ward, Acta Crystallogr. B72 (2016), 171-179; (b) F.H. Allen, Acta Crystallogr. B58 (2002) 380-388.

[28] V.Y. Sosnovskikh, V.A. Kutsenko, Russ. Chem. Bull. 48 (1999) 540-551.

[29] (a) S. Sharif, G.S. Denisov, M.D. Toney, H.-H. Limbach, J. Am. Chem. Soc. 128 (2006) 3375-3387; (b) T. Dziembowska, M. Szafran, A. Katrusiak, Z. Rozwadowski, J. Mol. Struct. 929 (2009) 32-42; (c) B. Kukawska-Tarnawska, A Leś, T. Dziembowska, Z.J. Rozwadowski, J. Mol. Struct. 928 (2009) 25-31; (d) A. Başoğlu, S. Parlayan, M. Ocak, H. Alp, H. Kantekin, M. Özdemir, Ü. Ocak, Polyhedron 28 (2009) 1115-1120.

[30] W.R. Roush, P.T. Grover, J. Org. Chem. 60 (1995) 3806-3813. 
[31] F.H. Allen, O. Kennard, D.G. Watson, L. Brammer, A.G. Orpen, R. Taylor, J. Chem. Soc., Perkin Trans. 2 (1987) S1-S19.

[32] J.-T. Liu, F.-L. Zhao, Synthesis (2003) 2307-2310.

[33] S.V. Ryabukhin, A. S. Plaskon, E.N. Ostapchuk, D.M. Volochnyuk,O.V. Shishkin, A.A. Tolmachev, J. Fluorine Chem. 129 (2008) 625-631. 
- Synthesis of 1,4-diazepine by double condensation of TTA with ethylenediamine

- Synthesis of 1,5-benzodiazepine by double condensation of TTA with o-diaminophenyl

- X-ray crystal structures of both diazepines

1,4-diazepine exists as imine-enamine tautomer in solution and in the solid-state.

1,5-benzodiazepine exists as diimine tautomer in solution and in the solid-state. 